\title{
Inter-organisational Knowledge Networks: Synthesising dialectic tensions of university- industry knowledge discovery
}

\author{
Purpose \\ Despite growth in use of inter-organisational relationships for knowledge co-creation, many \\ collaborations struggle to realise the synergistic benefits of these networks. This research explores \\ the evolving dialectic tensions evident within an inter-organisational relationship and the \\ governance consideration to optimise the knowledge process.
}

\section{Design}

A longitudinal case of a university-industry knowledge network is selected for study. The single case analysis aligns with the dialectical epistemology, which dismisses the expectation of homogeny or constancy across network cases.

\section{Findings}

The research highlights the dialectic tensions evident within inter-organisational relations and the governance mechanisms developed to synthesis the network knowledge discovery capability. The research shows that these tensions are a natural part of network existence and often advantageous to knowledge creation. The research also highlights that governance is required at multiple levels within the network in order to optimise knowledge exchange and discovery.

\section{Originality}

The research adds to the limited application of dialectical thinking to inter-organisational networks. It highlights the structural and relational governance mechanisms that interact to optimise their knowledge process capability. It shows the multiple levels within networks at which tensions can originate, requiring knowledge governance at the micro, meso and macro level to address the complexity of the interorganisational relationship. This research provides a better understanding of how knowledge within interorganisational relations can be managed for mutual benefit and value creation.

Keywords: University-industry collaboration, knowledge discovery, governance mechanisms, dialectic thinking. 


\section{Introduction}

Our understanding of the process of organisational innovation and its management has evolved in recent decades (Rothwell, 1992; 1994). Central to this is that innovation rarely involves a single technology or market but rather a bundle of knowledge which is brought together into a configuration. It is about accessing and using knowledge about components but also about their integration (Tidd and Bessant, 2005). The current perspectives of the innovation process view it as an interactive and networked system that spans organisational boundaries to draw on diverse sources of knowledge, experience and capabilities to achieve organisational objectives (Rothwell, 1992; Chesbrough, 2003; Sydow et al, 2016). The use of inter-organisational alliances, partnering and collaborations is an increasingly common way of learning and achieving organisational innovation objectives (Beamish, 1988; Hagedoorn, 1995; Powell et al, 1996; Inkpen, 1996). Syndow (2016) identifies the three types of inter-organisational relationships as being: market, hierarchical and networked relationships. The market and hierarchical types view knowledge more as an asset while the networked perspective views knowledge as the output of the interaction process between organisations. The networked type of inter-organisational relationship is deemed the most collaborative type, striving to deliver output of mutual benefit (Sydow et al., 2016) and thus often poses significant challenge for management. Networked relations between organisations, especially knowledge-rich entities such as universities and industry research organisations, can bring together collective knowledge that allows peer reflection and confronting of 'unknowns' (Brown and Duguid, 1991). This leads to learning and new knowledge (von Glaserfeld, 1995). Collaboration with such complementary partners can facilitate knowledge discovery that otherwise might be outside the scope of an individual organisation's capability (de Faria et al, 2010). Through slackening the organisational boundaries, organisations are able to harness externally controlled resources to address gaps in internal knowledge and achieve resource synthesis to respond to ever increasing dynamic environments (Becheikh et al., 2006; Bojica et al., 2018; Dooley et al, 2016; Kang and Lee, 2008; Romijn and Albaladejo, 2002).

While inter-organisational networks are increasingly a legitimate way to nurture innovation, the success of such alliances is questionable (Spekman et al, 1996; de Rond, 2003). The challenges relate to interorganisational networks being social phenomenon, where dialectical tensions influence the network's operation and performance (Nonaka and Toyama, 2002; Sydow et al, 2016). Research on knowledge exchange identifies characteristics such as embeddedness within networks (Fritsch and Kauffeld-Monz, 2010), spatial proximity to network partners (Audretsch \& Feldman, 1996; Fritsch and Slavtchev, 2007) and strong ties (Fritsch \& Kauffeld-Monz, 2010) as enablers of the knowledge process and learning. However, Fritsch and Kauffeld-Monz (2010) caution against the general interpretation of network factors. They emphasise the importance of context such as the network's stage of development and they call for more research on more established networks. Gaining a better understanding of network dynamics in terms of the routines, control and co-ordination mechanisms is advantageous, not only for enhancing capability to leverage and synthesis complementary external resources for innovation but also in illuminating the 'blackbox' of inter-organisational 
functions (Wood and Gray, 1991) under which multiplexity develops (Bojica, 2018) of the desired multiple knowledge connections between partner nodes within and across relationships. Additionally, this deeper understanding is advantageous to realisation of the triple helix model of University-Industry-Government collaboration (Etzkowitz and Leydesdorff, 2000) and the entrepreneurial university ideal (Etzkowitz et al., 2000) since creating an effective inter-organisational network between the stakeholders of University, Industry and Government is essential to nurture scientific/ technological development and knowledge spill-over for the National Innovation System (NIS) (Etzkowitz and Leydesdorff, 2000).

The research explores the developing governance ${ }^{1}$ of an inter-organisational knowledge process and the dialectic tensions that have influenced the network development. This study applies a dialectical thinking perspective (de Rond and Bouchikhi, 2004) as an analytical lens to better understand knowledge exchange and discovery within a multi-partner university-industry network case. The study first seeks to understand the underlying structures, routines and contextual factors of the knowledge process (Bouncken et al., 2016). Secondly, it strives to better understand the impact of dialectical tensions on the knowledge processes of interorganisational knowledge networks and how management govern engagement for synthesis and knowledge discovery. In adopting a dialectical thinking perspective, this research departs from a positivist perspective with regard to the homogeneity of best practice for inter-organisational relationships and instead adopts a more constructive discourse on knowledge management within inter-organisational networks that "would leave aside any monist expectation of order, homogeny, teleology, constancy, life span, or success and approach alliances as "facts" instead" (de Rond and Bouchikhi, 2004; 67).

The remainder of the paper is structured as follows. The next section provides an overview of the interorganisational network literature and university-industry collaboration literature relevant to understanding the dynamics of knowledge process governance within inter-organisational networks. Section 3 discusses the methodology employed in this research. Section 4 presents the case findings, providing an overview of the case study's collective knowledge process and through adoption of a dialectic thinking perspective, reflects on network governance considerations implemented to nurture knowledge discovery across network nodes. Section 5 presents a discussion of the research findings in light of existing theory and managerial practice.

\section{Inter-organisational Knowledge Network Management}

The establishment of inter-organisational networks is not solely a strategic issue but also an organisational and managerial one (Ring and Van de Ven, 1994; Child et al, 2005; Syndow et al, 2016). The motives of firms co-operating in networks include cost reduction, risk reduction, access to scarce resources, market access, access to new technologies to speed up product development and commercialisation, increased capacity, knowledge co-creation and to pool complementary knowledge and skills (Cerchione and Esposito, 2016;

\footnotetext{
${ }^{1}$ The etymology of Governance aligns with Farrar's (2008) perspective of the idea of steering a ship, ensuring control and maintenance of good order within the network to achieve stakeholder benefit.
} 
Ilvonen and Vuori, 2013; Kogut, 1989; Kleinknecht and Reijnen, 1992; Hagedoorn, 1993; Eisenhardt and Schoonhoven, 1996; Powell, 1998; Robbins-Roth, 2001, Tidd et al, 2005). Inter-organisational networks are neither a new phenomenon nor one confined to big business; they are driven by market, hierarchical and networked forces (Syndow, 2016) and can engage any size or sector of organisation. In the innovation context, inter-organisational networks commonly seeks to harness the knowledge discovery and learning benefits of engagement between commercial industry and publically-funded research entities (e.g. Universities) for mutual benefit. In bringing complementary knowledge from diverse sources together through engagement then there is significant scope for knowledge synthesis, learning and innovation.

Insights on knowledge and learning can be drawn from both the knowledge management and organisational learning with alliances literatures. Indeed, Beeby and Booth $(2000 ; 86)$ highlight the "potential for crossfertilisation of ideas within and across the fields" but also highlight the differences in the perspectives. The knowledge management literature views knowledge acquisition/creation/integration by networks as a means to an end (e.g. competitive advantage), whereas the learning organisation literature promotes a more collaborative rationale for the network existence (ibid). Networks create value by synthesising information and knowledge, exploiting expertise and pooling resources across traditional boundaries in order to create new knowledge and achieve innovations outside of individual capabilities and the resource bases of individual organisations (Prasad and Akhilesh, 2002; Johnson et al, 2001; Ratcheva and Vyakarnam, 2001; Pawar and Sharifi, 2000; Trott 2008). Knowledge networks function because key individuals behave as 'knowledge brokers' (Hargadon, 2002), possessing the ability to cross knowledge and organisational boundaries and provide ties that nurture the flow of knowledge both within the network and between the network and the larger external environment (Granovetter, 1976). The value of these individuals lies not only in their ability to traverse network boundaries (both physical and knowledge based) but also in their ability to make sense of the network's dynamic complexity (Senge, 1990) and navigate the dialectical tensions that influence its operation and performance (De Rond and Bouchikhi, 2004).

Unfortunately, the synergistic benefits of an inter-organisational network are not automatic and are influenced by "how effectively linkages... are actually managed" (Gupta and Govindarajan, 1986: 696). Barringer and Harrison (2000) emphasize the complex and speculative nature of inter-organisational networks, in that "many inter-organisational relationships fall short of meeting expectations of their participants or fail for other reasons" (Barringer and Harrison, 2000; 368) and "in the end, the decision to participate in an interorganisational relationship must be a probabilistic assessment of strategic rather than economic value" (Barringer and Harrison, 2000; 396). The ability to manage knowledge exchange within networks effectively, even within more transactional focused interactions (market type or supply chain relations) is recognised as "an increasingly critical factor in governing" (Cerchione and Esposito, 2016; 277) inter-organisational networks. Additionally, learning through such networks depends upon the extent to which the various organisations possess the "absorptive capacity" (Cohen and Levinthal, 1990) to be able to recognize the value 
of the new knowledge and adopt the dynamic capabilities required to exploit them (Teece et al, 1997; Nonaka and Toyama, 2002). Governance challenges and network under-performance can be traced to issues such as failure to integrate routines and cultures of collaborating organisations (Spekman et al, 1996; de Rond, 2003), failure to align realistic and mutually beneficial objectives (Doz and Hamel, 1998), failure to achieve the synergistic resource mix of knowledge and network ties (Gubbins and Dooley, 2013), inadequate asymmetry in the resources invested in the network's activities (Farrar, 2008) and ineffectual management of tensions inherent in network governance (Provan and Kenis, 2008). The relative impact of these challenges on knowledge exchange in a network and the potential implications for network governance can depend on the phase of development of the network and the unique context within which it is based (Fritsch and KauffeldMonz, 2010). When discussing the relationship between knowledge and governance, Foss (2013; 66) states that although some view knowledge characteristics as independent variables driving governance, there "is nothing wrong in treating 'knowledge' as both a dependent and independent variable" since knowledge characteristics can influence the nature of governance but it is also possible that governance mechanisms will influence the knowledge synthesis process. Thus, it may be useful to view network tensions and the governance mechanisms used to manage them as complementary rather than competing forces within the dynamics of inter-organisational network knowledge processes.

This complexity of managing network operations is reinforced by Sydow et al, (2016; 22); “interorganisational relationships are social phenomena characterized by several contradictions, simultaneously arising from pluralistic interests, unintended consequences, conflicting values or idiosyncratic relational histories... [and] these tensions and contradictions... cannot - and should not- be dissolved, because they form the very specific character and advantage of this organisational form. Rather they have to be managed". In exploring this complexity, de Rond and Bouchikhi, (2004; 56) distil four generic theories from Van de Ven and Pooles's (1995) topography of process theories "which speak well to dynamic processes in organisation life; life cycle, teleology, evolution and dialectics". The latter of these perspectives is dialectical thinking, where multiple coexisting contradictory forces collide to produce a new social order and in an organisational context, will compete for scarce resources and managerial support, generate conflict and undermine and adapt organisational arrangements (de Rond and Bouchikhi, 2004; 58). Das and Tang (2000a; 2000b) leverage dialectical thinking to understand alliance instability and failure, suggesting internal tensions (cooperation versus competition, rigidity versus flexibility and short-term versus long term orientation) nurture alliance stability when kept in balance. Building on Das and Tang's contribution, de Rond and Bouchikhi (2004) develop a larger set of eight dialectical lens (see figure 1) which influence inter-organisational dynamics and require management. While both research teams highlight the value of dialectic thinking as a way of examining dynamic processes within such networks, De Rond and Bouchikhi (2004) caution of Das and Tang's suggestion that the presence of tensions between pairs is an indicator of instability and failure, instead viewing them as a natural part of network existence and suggesting management should endeavour to steer interorganisational relationships to synthesise competing tensions rather than strive for compromise and 
equilibrium.

In managing the tensions and contradictions of alliance complexity, Faems et al (2008) identify two theoretical perspectives of network governance; the structural and relational perspectives. The structural perspective of alliance governance is grounded in event and transactional cost theory (Williamson, 1985), where partners are perceived as opportunistic in nature and where initial structural design (e.g. contract) is core to explaining network performance. The relational perspective is grounded in the relational dynamic and social exchange theory (Blau, 1964), where a network is dynamically evolving through multiple transactions, its partners are perceived as trustworthy and on-going relational management is important in explaining performance. Tepic et al (2011) identify structural governance mechanisms, explicit in agreed documentation, as a trade-off between incentives and administrative control. Conversely, relational governance mechanisms emerge as a consequence of social relationship exchanges, based on implicit understandings rather than formalised position. Rather than both perspectives being considered mutually exclusive, Doz (1996) promotes the relatedness of these alliance governance perspectives and numerous researchers (Faems et al, 2008; Contractor, 2005; Madhok and Tallman, 1998; Tepic et al, 2011) have subsequently identified the need for greater study of the interplay between the structural and relational dimensions of alliances

\subsection{University-Industry Knowledge Network}

Against a background of an ever increasing knowledge requirement to support innovation, university-industry collaborations, as one form of inter-organisational knowledge network, are viewed as a highly important mode of collaboration, advantageous to the National Innovation System (NIS) (Etzkowitz and Leydesdorff, 2000) and competitiveness of regional firms (Philpott et al, 2011). Prior to the triple helix model of UniversityIndustry-Government collaboration (Etzkowitz and Leydesdorff, 2000), the traditional mission of the university was focused on knowledge transfer through education and dissemination of research output. Together with this dual mission of teaching and research, many universities now adopt a third mission of economic development through purposeful academic engagement with industry. While supportive of the practice of university-industry engagement, both Philpott et al (2011) and Perkmann et al. (2013) caution the assumption that such university-industry collaboration is always beneficial. They highlight that such interactions should be managed to avoid adverse impact the traditional academic missions of teaching and research. The channels of university-industry interaction can broadly be defined into four categories; 1) research support, 2) technology transfer, 3) knowledge transfer and 4) cooperative research (Santaro, 2000). Jacob et al (2000) refer to the latter of these as 'the fourth phase of academy-industry relations' where deeper relations are required between stakeholders to shift focus from sponsorship to partnership and shift outcome from knowledge transfer to co-creation. Exploratory focused university-industry knowledge networks exist within this latter category, where engagement is advantageous to both sectors and the objective is to achieve knowledge synthesis for mutually beneficial knowledge discovery breakthroughs. When examining the relationship between knowledge management and the innovation processes, Tranfield et al (2006) identify 
generic knowledge phases that require management; these are the searching out, capturing and articulating knowledge associated with the discovery phase, the contextualisation and application of knowledge associated with the realisation phase and finally, the evaluation, supporting and re-innovating of knowledge associated with the nurture phase of innovation. Thus for a university-industry knowledge network to deliver collective benefit, then each of these phases of the knowledge process must be managed (e.g. governance) to achieve the desired knowledge synergies and discovery breakthroughs.

Elmuti et al (2005) state that although there is evidence to indicate the power of university-industry collaborations, "the intensity of these relationships and the tangible outcomes generally lags behind". Aligned with this perspective, Huggins et al. (2012) highlights there is need for much greater focus on the nature and patterns of interactions emerging from university-industry practices. Collaborations between university and industry research organisations can be challenging since much of the knowledge resists effective transfer due to the 'encultured' expertise embedded in specific routines and the distinctive scientific language (Blackler, 1995). Likewise, ability to exchange knowledge across organisational boundaries will influence the trust and strength of ties existing between individuals within the network (Levin and Cross, 2004). Given the cultural differences (and institutional priorities) of the university and industry sectors, it can take significant time and stakeholder commitment to achieve the affinity and cognitive proximity to achieve the desired synthesis of individual partners knowledge. Thus, examining the context of such a university-industry knowledge network offers a rich context to explore the inter-organisational network knowledge process, the tensions present and the routines and structures that govern knowledge synthesis.

\section{Methodology}

When the research question examines the "how" and the "why" in regards to certain issues (as is the focus in this research), then Yin (2002) suggests that the use of case studies, histories and experiments may be most applicable. In exploring the dynamics of the knowledge process within inter-organisational networks, the research adopts a qualitative approach and explores a university-industry knowledge network of multiple partners collaborating on exploratory research within a specific area. Qualitative analysis offers the potential of deeper understanding of the dynamics of interaction within the knowledge creation network and scope to explore the meaning of actions in developing new knowledge for potential benefit (Riege, 2003; Jack, 2005). The evolution of knowledge networks takes time and thus the case selected for this research has been under longitudinal study for the period 2004-2014 (see Authors, 2013). Continued engagement by independent partners, together with resource commitment to support the network activities is deemed a reasonable proxy for the quality of the network's knowledge creation and justifies it as an interesting case for the study of interorganisational knowledge creation. The decision to focus on a single case for this study was influenced by the dialectical epistemology which dismisses the expectation of homogeny or constancy across cases and application of the set of alliance dialectic tension pairs identified by de Rond and Bouchikhi (2004) (figure 1) as an analytical lens for understanding governance of the network's knowledge management process. 


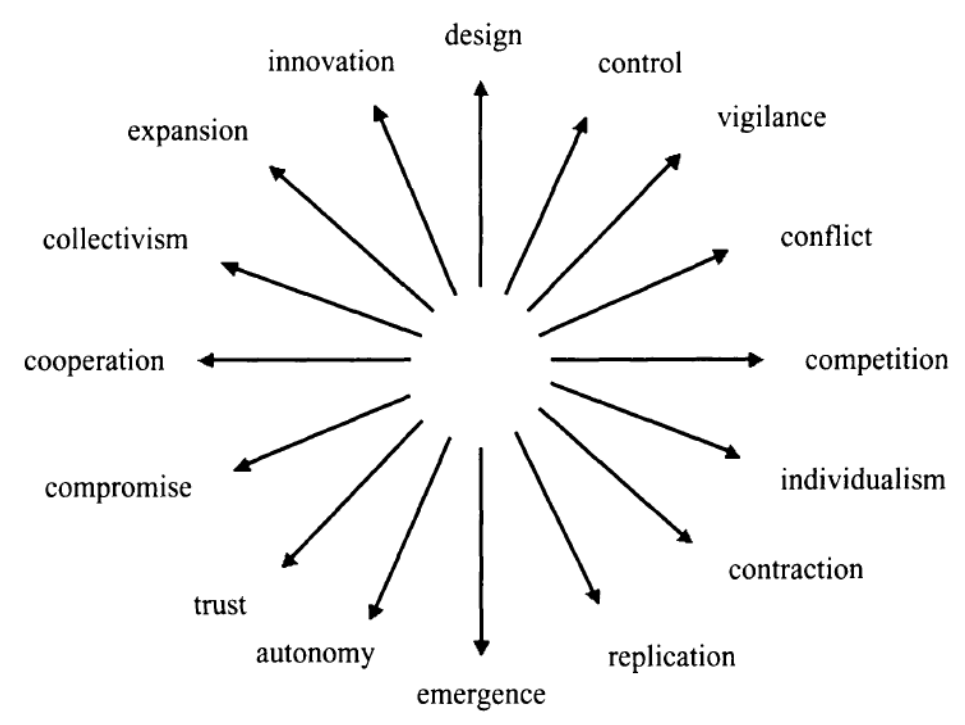

Figure 1: Alliance dialectical tensions (de Rond and Bouchikhi, 2004)

The case study in question is that of a university-industry life-sciences network, established in the late 1990's for the purpose of advancing frontiers within a specific scientific domain and which has recently entered its $5^{\text {th }}$ cycle of contractual renewal. This particular inter-organisational network is an exploratory research focused collaboration, centred at the research centre of a well-resourced and internationally recognised university, where 5-6 pharmaceutical organisations and a Government funding body collaborated to combine research and development resources for mutual benefit. The case study was developed through undertaking semi-structured interviews of network stakeholders at 24-30 month intervals on a post-facto basis, where respondents' accounts of decisions taken, motives and outcomes had gained the benefit of hindsight. Purposive sampling (Stewart 1998) was used to identify interview respondents and a commitment of anonymity was provided to facilitate full access to the network operations and openness from respondents. Interviews focused on the process by which scientific discoveries were realised within the collaborative network and the enablers and barriers that impacted this process. While primary data was collected through semi-structured interviews, its triangulation was further supported by secondary data collected at the time of interview (e.g. annual reports, network databases and university documentation) to ensure validity. The semi-structured interview process was guided by a protocol, which prior to each cycle of interviews, was reviewed and amended in light of past case analysis. The protocol addresses six key areas; motives and commitments of 'parent' organisation, knowledge exchange and discovery collaboration, management structures and routines, critical incidents (successes and challenges), recruitment/renewal phase of network and future network continuation (opportunities and threats).

Interviews took place periodically over the period 2004-2014 with relevant stakeholders from the UniversityIndustry-Government parties and lasted between 1-3 hours. Visits to the university site often included visits to the research centre's laboratories and more informal discussions with operational level scientists. Given certain respondents were interviewed multiple times over the research period, it was possible to follow-up on 
themes and discrepancies from the previous interview rounds and seek clarification, if necessary, from respondents. Thus, comparison of the accounts of the development of each network was feasible and provided a means to explore common pattern across the networks. Interview transcripts were thematically analysed following each cycle of interviews and an individual 'case-study' was written up in accordance with best practice (Eisenhardt, 1991; Gummesson, 2000). Given the centrality of the knowledge process within interorganisational relations, the case was structured using Transfield et al.'s (2006) phases as a template for the narrative. To ensure validity and reliability of the case in representing the reality of the network, the draft case was periodically returned to the consortium lead for review and comment. This feedback further deepened insights of the network's knowledge process. For the purpose of a deeper understanding of the dynamic processes governing the inter-organisational network's knowledge process, this research applies an embedded layer of case analysis through exploring the influence of each of the eight pairs of dialectical tensions (de Rond and Bouchikhi, 2004) (see Figure 1) on the routines steering collaborative knowledge exchange and discovery across the network.

\section{Findings}

\subsection{Case background}

The case is a university-industry life-sciences network, which has demonstrated significant resilience in maintaining partner commitment over 18 years and reaching its $5^{\text {th }}$ cycle of renewal. The network was initially established by the Principal Investigator (PI), who envisioned harnessing the collective university and industry research capabilities for mutual benefit and advancement of his specific research area. Over its lifetime, the network has evolved in response to both internal and external stimuli and this has resulted in the network that exists today and the governance mechanisms that guide knowledge exchange. This particular interorganisational network consists of a world class university research centre, 5-6 industrial partners (depending on funding cycle) and a national research funding body. Although the funding body is not a direct contractual partner in the network's operations, their ongoing funding of the university research centre, in terms of infrastructure and funding support of the university research capability, makes them central within the network and thus their requirements must be accommodated.

The motives for engagement from the university partner perspective is that it enhances their internal research capability by providing access to the complementary scientific endeavourslcompound libraries of industrial partners, increases funding available to undertake more research and provides evidence for funding agency proposals of effective translation of science discoveries for societal benefit. The motives from an industrial partner perspective include access to a rich reservoir of scarce proprietary knowledge which they currently lack, access to world-leading research scientists, security of a 'bounded' network for opportunity scanning, and speeding up the process of research translation from university to industry. The embedded nature of the scientific knowledge impeding more traditional modes of knowledge transfer mechanisms was also a key motive for the formation of this network. While these were the initial drivers of collaboration by the partners, 
sustained interactions have afforded them additional pecuniary and non-pecuniary benefits that enhance their innovation capabilities (see table 1). Funding bodies view the network as complementary to the traditional research activities of the university research centre, providing a unique synthesis of research capability and assets, capable of stimulating progress on important scientific frontiers and providing a more effective means of knowledge transfer of public research into the industrial $R \& D$ process and for societal impact.

\begin{tabular}{|c|c|}
\hline University partner benefit & Industry partner benefit \\
\hline \multicolumn{2}{|c|}{ Perceived at Network Outset } \\
\hline Advancing the discipline state of the art & Advancing the discipline state of the art \\
\hline $\begin{array}{l}\text { Access to additional source of funding to acquire additional } \\
\text { facilities and staff }\end{array}$ & $\begin{array}{l}\text { Access to scarce knowledge and expertise to fill internal } \\
\text { knowledge "structural holes' }\end{array}$ \\
\hline $\begin{array}{l}\text { Access to proprietary resources from industry such as library of } \\
\text { reagents and inhibitor compounds }\end{array}$ & $\begin{array}{l}\text { Access to increased resources (human and infrastructure) } \\
\text { located within university }\end{array}$ \\
\hline \multicolumn{2}{|c|}{ Perceived During Network Collaboration } \\
\hline $\begin{array}{l}\text { Access to increased pool of knowledge and experience from } \\
\text { industry scientists }\end{array}$ & $\begin{array}{l}\text { Advanced and often exclusive access to university intellectual } \\
\text { property emerging from the research }\end{array}$ \\
\hline $\begin{array}{l}\text { Ability to leverage externally generated funds as matched } \\
\text { funding to acquire additional public research funds }\end{array}$ & $\begin{array}{l}\text { Scaling of scanning ability through collective pooling of } \\
\text { resources and funding. }\end{array}$ \\
\hline Enhanced reputation within the research arena & $\begin{array}{l}\text { Ability to leverage additional public funding (direct and indirect) } \\
\text { to support R\&D capacity }\end{array}$ \\
\hline $\begin{array}{l}\text { Evidence of translation of research for societal impact and even } \\
\text { commercial potential to leverage future public-research funds }\end{array}$ & Access to increased network of industrial scientists and expertise \\
\hline $\begin{array}{l}\text { Fore-sighting of emerging research areas with high potential for } \\
\text { commercial exploitation. }\end{array}$ & Enhanced reputation within the research arena \\
\hline
\end{tabular}

Table 1 University-Industry partner benefits gained from collaboration

\subsection{Knowledge exchange}

Recognising the motives and potential value for all stakeholders, the academic PI's leveraged their contacts, both within the university and externally within the industry community, to develop the university-industry network for knowledge exchange and innovation. The effectiveness of the routines guiding the network's knowledge process are central to the delivery of value from this inter-organisational relationship. Across the years of operation, the network's management team has endeavoured to stimulate each of the knowledge management phases of discovery, realisation and nurture (Tranfield et al., 2006) to advance the scientific area by introducing both structural and relational governance mechanisms (Farrar, 2008). Achieving effective knowledge exchange across the network required managing linkages and relations at three levels; relations within the networked entity itself where the knowledge resources were synthesised through experimentation (micro-level), relations between the network entity and the supporting independent organisations (meso-level) and finally, relations between the network and the external scientific environment (macro-level). Although the network's governance structure appears largely unchanged since initial establishment, this perception of stability hides the tensions and negotiated synthesis that are a natural part of the networks development for enhanced knowledge exchange, learning and innovation. After formation, it took a number of years to achieve a critical mass of knowledge exchange and output that justified partner commitment and thus adopt a longterm perspective needed to be adopted by all partners towards the collaboration. 


\section{Knowledge discovery}

The knowledge discovery phase is composed of the routines of search-capture-articulate (Tranfield et al., 2006) and relates to how the network identifies potential sources of knowledge of value and secures access so the knowledge can be transferred within the network. The searching out and selection of appropriate organisational partners with complementary knowledge initially was championed by the academic PI network, leveraging their contacts and the international reputation of their research centre to 'sell' the value potential to prospective partners. Given the scientific focus of the network's activities, the 'bringing together' of complementary knowledge from university and industry sources not only creates a critical mass of knowledge but also diversity of perspective to stimulate creativity and innovation. As the network matured and benefits are realised by the partner organisations, the organisation representatives have also become champions, seeking out new knowledge sources, advantageous for the network's knowledge discovery process. The renewal of contract agreements each 4-year period provides the opportunity for the introduction of new knowledge sources identified in the search activity. As the network's reputation for knowledge discovery and value creation has developed, the scope of knowledge sources available to the network (both internally available from existing partners and externally from potential new entrants into the network) has increased and the 'selling' challenge reduced.

"it was much easier to get the partners to sign-up again during the [network] renewal phase as their doubt had been answered" [AC1-C]

In terms of the routine of capture/access (Tranfield et al., 2006) to proprietary knowledge sources, this occurred when partner organisations signed-up and contractually agreed their commitment of resources. Although the structural governance of a legal contract and the network being 'bounded' in terms of membership provided partner representatives with the initial reassurance to engage in knowledge exchange, it took time for trust and routines to develop between the partners to support the knowledge flows. As confidence in the network routines developed, partner representatives provided access to additional knowledge sources complementary to the network activities, something that further stimulated discovery capability in a virtuous cycle.

“.. the consortium is going for a number of years, people stand back and realise ... these people aren't leaky.... they don't tell other people.... and once that happens then the people began to open up a bit more and ... there is some more interesting compounds begin to come through to you. " [AC3-D].

Despite the network providing both identification of and access to advantageous knowledge sources, articulating such knowledge for transfer proved challenging. Knowledge articulation was curtailed due to the tacit nature of scientific knowledge and the uncertainty of scientific outcomes from exploratory focused 
research. In an effort to overcome this challenge, partner organisations nominated representatives to the network's management team who were senior scientists, knowledgeable in both the scientific area and their organisation and also well positioned to behave as 'knowledge brokers' to connect other scientists with the knowledge outputs of the network.

"Each company has assigned an individual to get value from the consortium and to get the information out to the relevant people within their organisation... however this puts a lot of responsibility on this individual... the relationship between the consortium and the individual companies is very much based on the relationship with that individual" [AC1-D].

Ongoing management efforts to nurture access and articulation of the knowledge sourced (together with the later stages of knowledge contextualise-apply) resulted in the introduction of both structural governance routines around the network's operational procedures and relational routines, focused on deepening relationships through increased human interaction. Structural routines implemented within the network included scheduled on-site collective visits at the university research centre, access to centralised secure laboratory information systems, an agreed schedule of experimentation and harmonisation of laboratory practice regarding documentation of experiments. The relational routines to support knowledge discovery emerged as individuals overcame challenges in achieving knowledge capture and articulation and included developments such as co-location of industry staff in the university for short periods, one-to-one discussions between researchers, introduction of social gatherings for partner representatives and increased communication at conferences or via email and telephone. Another contributing factor to the network's ability to capture and articulate knowledge sourced was the long-term, yet definite duration of the network cycle (4 years). This provided a period of stability for peer-to-peer relations to develop between network members. Likewise, the 'neutral ground' setting of the university provided a suitably supportive physical and cognitive environment for exchanging tacit knowledge and nurturing knowledge creation.

"It's great... spending time with like-minded individuals who have a focus on where the science is going and what it might be used for" [ID1-A].

\section{Knowledge realisation}

The knowledge realisation phase of contextualise-apply (Tranfield et al., 2006) relates to how the network absorbs the transferred knowledge from partner organisations and applies this knowledge to advance scientific understanding. A number of 'human interaction' initiatives to enhance knowledge articulation have also benefited its contextualisation once transferred. For example, the high calibre of individuals engaged in the network had a sufficient base of scientific knowledge and organisational knowledge to be in a position to contextualise that knowledge. Likewise, the commitment of partner representatives meant that sufficient time 
was made available to help those tasked with contextualising the knowledge to articulate it and re-articulate it, a process of constant two-way communication, to enable effective contextualisation.

The collective knowledge available within the organisational actors is applied to solve specific scientific problems, as part of an agreed schedule of experimentation, mutually beneficial to the network participants. Emergent learning and discovery arises through the sharing of similar socially agreed ideas and technical skills with other peers and the focused experimentation of peer scientists across the network. The longevity of the knowledge network, both in terms of duration (e.g. five cycles to date) and the consistency of industrial partners has afforded time and strength of purpose for collective research to mature and generate a legacy of scientific discovery for future scientific advancement to build on. Emerging results of the research activity are reflected upon by the partner representatives and contextualised relative to their own organisational objectives and the current state of the art within the scientific community. Following such reflection, decisions regarding new avenues of exploration are taken. Many avenues are pursued collectively but also some on a one-to-one basis as network members envision new ways to leverage value from the collaboration. While such tangential, one-to-one projects are permitted, strong oversight of these supplementary initiatives by the network's management team is necessary to avoid causing conflict between partners.

"We wanted access to their compounds for our research and they [industry organisations] wanted access to our capability and discoveries in order to accelerate the development of these compounds into leads for drugs and new forms of income for the company" [AC2-A].

\section{Knowledge nurture}

The knowledge nurture phase of evaluate-support-re-innovate (Tranfield et al., 2006) relates to how the network maintains and enhances advantageous knowledge exchange within the network for the mutual benefit of all partners. As defined in the contract agreements and network routines, partner organisations support the network through both financial and knowledge resources for a defined 4-year period. The quality of the scientific discoveries produced by the network, together with the individual partner's due diligence of the alignment of these outputs with the strategic trajectory of their organisation, during contract renewal, determines continued support. The knowledge discoveries generated by network activities have resulted in leads for exploitation through patents, new treatments and new methods of working. These have generated significant stakeholder value for partner organisations as inputs to their own innovation process or as initiatives for joint development. The knowledge value generated has ensured consistency in partner involvement, allowing this inter-organisational knowledge network to evolve and grow in terms of research capacity and scope.

While network success has generated strong partner goodwill with respect to knowledge exchange and commitment to network activities, its evaluation and decision to re-enter another contract cycle (re-innovate) 
is a rational one, solely based on benefit to individual organisations. While the majority of partners have continued within the network, there are a small number of firms that exited due to shifts in their parent organisation's scientific objectives or other macro environmental factors. While introduction of new partners into the network has been advantageous for its re-innovation, it also results in tensions until the new partner becomes embedded within the routines of the network. Thus, this re-innovation phase is carefully managed by the academic PI, engaging in contract re-negotiation on a one-to-one basis between university and industry partner and endeavouring to find alignment in objectives of both. While this is not always possible since core network objectives must be maintained, this re-innovate phase has resulted in alterations to the focus of certain projects, introduction of right of veto over entry of new members and modifications regarding the networks governance, all intended to entice partner research capability into the network for future scientific advancement and knowledge creation.

\subsection{Dialectic tensions and knowledge governance}

This knowledge network has existed from almost two decades and while certain partner organisations have changed, the overall objective of synthesising collective knowledge for the advancement of the scientific frontier has remained constant. The governance mechanisms (structure, routines and norms) in place to nurture the inter-organisational knowledge management process have evolved over the years as key individuals endeavour to 'steer' collective operations in the absence of control resting with one particular organisation. Governance is traditionally related to ownership/control (Farrar, 2008) but within the context of a multiple organisation context, no absolute ownership exists, especially given the uncertainty of outcomes related to exploratory research. The governance routines under which multiplexity has been achieved is a product of both planned and serendipitous interventions, often in response to tensions perceived to be curtailing knowledge capability. Network governance was originally grounded in the structural governance of the interinstitutional contractual agreement but as human interaction exchanged knowledge, then impediments and tensions began to emerge and this drove the desire for further governance enhancement. Understanding the tensions occurring across the network and their influence on governance interventions provides a deeper understanding of how multiple organisations can achieve mutually beneficial knowledge exchange and discovery. Reflecting on the manifestation of the tensions across the networks multiple cycles of development (Chao, 2011) highlights the complexity of network operations and the ebb and flow of tensions depending on the particular context. Table 2 presents an overview of the manifestation of some dialectic tensions across the three development phases of one contractual cycle of the network and the governance considerations arising from same. Applying the eight dialectic pairs (de Rond Bouchikhi, 2004) as an analytical lens shows that all tension pairs are present during network operations, often with tensions within multiple dialectic pairs occurring simultaneously. The presence of these multiple tensions were sometimes complementary to each other and other times in conflict with one another. For example, when initially established, network tension within the individual-collectivism and trust-vigilance dialectic pairs were skewed towards a transactional perspective, with partner trust being low and instead these independent organisations being highly vigilance 
of each other's actions in order to minimise the risk of individualistic behaviours. The presence of these tension resulted in structural governance being explicit in terms duration of partner commitment (e.g. four years) to allow space to nurture cognitive proximity through deeper relationships and for the critical mass of knowledge synthesis necessary to validate independent partner participation. The result of the stability provided by this aspect of the structural governance sustained the interaction and learning between network partners that increased trust and generated a greater sense of collectivism within the network.

"It took 12-months to agree the consortium agreement... a direct result of the scale and complexity of the proposed collaboration" [AC1-A]... [but at renewal time] "it was much easier to get the partners to sign-up again during the [network] renewal phase as their doubt had been answered" [AC1-C]

As interaction and exchange of knowledge was realised across the network, new opportunities identified by partner organisations began to altered tension (e.g. the control-autonomy dialectic pair) and stimulate new governance mechanisms to facilitate pursuit of the opportunity. In this case, opportunity identification required partner representatives to relax the control of their 'stewardship' to allow individual researchers greater autonomy to pursue opportunistic research trajectories. This decision resulted in a shift in the controlautonomy tension and also the design-emergence tension by introducing more informal knowledge exchange routines based on goodwill and opportunity (relational governance) to complement structural mechanisms and nurture the network's knowledge management capability.

“... the commitment of the partner reps as key... their leading from the front gave others in their organisations the encouragement to get involved" [AC1-A]

Analysis of the dialectic pairs (table 2) highlights that all pairs have the potential to influence governance mechanisms. Analysis of the tensions present in the network reinforces the interrelationship between dialectic pairs (e.g. tension in one dialectic pair can spark of tension elsewhere in other tension pairs) but also shows that cause and effect was not always linear and instead a factor of the complexity of a multiple partners knowledge system. Analysis of the tensions within dialectic pairs also demonstrates that they occur at three distinct levels of network existence; the operational level of individual interaction for knowledge exchange and discovery (micro), the inter-organisational interaction between independent partner organisations and the network entity itself (meso) and finally, the alignment between the network entity and the global state of the art within the particular knowledge domain (macro). The tensions occurring across the network lifecycle are a synthesis of tensions at these multiple levels of inter-organisational collaboration (macro, meso and micro). An example of tension across these multiple levels of the network occurred during the first renewal phase, when an existing partner raised concerns regarding the potential entry of a new partner. Discussions took place within the management team and with reservations, the existing partner ceded their individual concerns in favour of the collective potential benefit of additional knowledge that the partner possessed. The synthesis of 
this new knowledge store into the network proved fundamental in moving the network in a particular scientific trajectory and the resulting scientific discoveries appropriated value all members of the network, including the partner that had initial reservations. Therefore, this highlights the complexity of network interventions and that care must be taken when implementing new governance mechanisms since their impact on the network can manifest not only at the level they are focused at but at different levels of the network or even at a later time.

"Disputes as a consequence of differing organisational objectives or the scientific state of the art may be less prevalent but they have the potential to be more disruptive and likely to require intervention" [AC3-B].

\begin{tabular}{|c|c|c|c|c|}
\hline $\begin{array}{c}\text { Dialectical } \\
\text { Tension }\end{array}$ & Initialization/ Formation & Scientific operations & Reconfiguration/Renewal & Governance consideration \\
\hline $\begin{array}{l}\text { Design- } \\
\text { Emergence }\end{array}$ & $\begin{array}{l}\text { Strong structural design to } \\
\text { 'train' partners and } \\
\text { provide safe environment } \\
\text { for network cohesion. }\end{array}$ & $\begin{array}{l}\text { Organic development of } \\
\text { scientific trajectories through } \\
\text { experimental trial and error. }\end{array}$ & $\begin{array}{l}\text { Structural due diligence to } \\
\text { protect partner } \\
\text { organisations and } \\
\text { entrepreneurial recruitment } \\
\text { to stimulate knowledge. }\end{array}$ & $\begin{array}{l}\text { Synthesising stewardship to } \\
\text { parent organisations with } \\
\text { stimulating network } \\
\text { knowledge capability to } \\
\text { exceed status quo. }\end{array}$ \\
\hline $\begin{array}{l}\text { Control- } \\
\text { Autonomy }\end{array}$ & $\begin{array}{l}\text { Soft control of partners } \\
\text { through structural } \\
\text { governance nurturing } \\
\text { familiarisation and } \\
\text { respect. }\end{array}$ & $\begin{array}{l}\text { Autonomous teams pursuing } \\
\text { scientific trajectory with } \\
\text { periodic go/no go evaluations } \\
\text { by network management team }\end{array}$ & $\begin{array}{l}\text { Strong control of network } \\
\text { boundaries and right of } \\
\text { entry to new entrants. }\end{array}$ & $\begin{array}{l}\text { Synthesising the need for } \\
\text { control of collective action } \\
\text { with autonomy to pursue } \\
\text { emerging knowledge } \\
\text { opportunities. }\end{array}$ \\
\hline $\begin{array}{l}\text { Vigilance- } \\
\text { Trust }\end{array}$ & $\begin{array}{l}\text { Absence of relations } \\
\text { mean high levels of } \\
\text { vigilance and reliance of } \\
\text { structural governance }\end{array}$ & $\begin{array}{l}\text { Tipping point where trust of } \\
\text { other partner contributions is } \\
\text { automatic and synergies } \\
\text { develop where collective } \\
\text { exceeds individual. }\end{array}$ & $\begin{array}{l}\text { Strong relation respect of } \\
\text { members within network } \\
\text { but at this phase, individual } \\
\text { member stewardship to } \\
\text { home organisation increases } \\
\text { vigilance }\end{array}$ & $\begin{array}{l}\text { Importance of collective } \\
\text { trust for mutual knowledge } \\
\text { exchange existing in tension } \\
\text { with partner vigilance to } \\
\text { minimise opportunism. }\end{array}$ \\
\hline $\begin{array}{l}\text { Conflict- } \\
\text { Compromise }\end{array}$ & $\begin{array}{l}\text { Fluid interaction between } \\
\text { conflict and compromise } \\
\text { across stakeholders as } \\
\text { contractual terms agreed }\end{array}$ & $\begin{array}{l}\text { Conflict focused on science } \\
\text { rather than inter- } \\
\text { organisational issues with } \\
\text { evidence based proof rather } \\
\text { than compromise to resolve } \\
\text { differences. }\end{array}$ & $\begin{array}{l}\text { Comprise and negotiation } \\
\text { on part of university partner } \\
\text { as centrality and power in } \\
\text { network reduces as } \\
\text { industrial partners learn. }\end{array}$ & $\begin{array}{l}\text { Relational governance } \\
\text { nurtures interaction in times } \\
\text { of uncertainty and } \\
\text { turbulence, but can close off } \\
\text { more disruptive research } \\
\text { trajectories. Partners } \\
\text { reposition as relative power } \\
\text { and influence changes. }\end{array}$ \\
\hline $\begin{array}{l}\text { Competition- } \\
\text { Cooperation }\end{array}$ & $\begin{array}{l}\text { Exclusivity of knowledge } \\
\text { source and network } \\
\text { adequate to nurture } \\
\text { cooperation between } \\
\text { firms, especially when } \\
\text { confidence in sanction } \\
\text { routines develops. }\end{array}$ & $\begin{array}{l}\text { Strong competition internal as } \\
\text { teams compete for resources } \\
\text { to advance their research } \\
\text { trajectory. Developing culture } \\
\text { of meritocracy across } \\
\text { researchers. }\end{array}$ & $\begin{array}{l}\text { Commitment to renew } \\
\text { partner engagement based } \\
\text { on individual organisation's } \\
\text { perception of value gained } \\
\text { and future opportunities. If } \\
\text { re-engage then partner } \\
\text { reserves right to block } \\
\text { competitor entry. }\end{array}$ & $\begin{array}{l}\text { Structural governance } \\
\text { makes explicit partner } \\
\text { inputs and value } \\
\text { appropriation. However, } \\
\text { evolving routines stimulate } \\
\text { cooperative reciprocity to } \\
\text { advance knowledge } \\
\text { frontiers. }\end{array}$ \\
\hline $\begin{array}{l}\text { Individualism- } \\
\text { Collectivism }\end{array}$ & $\begin{array}{l}\text { Recognition within } \\
\text { network that collective } \\
\text { engagement required to } \\
\text { achieve knowledge co- } \\
\text { creation. }\end{array}$ & $\begin{array}{l}\text { Strong collegiality within } \\
\text { research teams but } \\
\text { competitive of incentives } \\
\text { drives competition. Given } \\
\text { defined time commitment } \\
\text { individual partner perspective } \\
\text { often reduced to maximise } \\
\text { eventual value capture from } \\
\text { the network. }\end{array}$ & $\begin{array}{l}\text { Despite representatives } \\
\text { commitment to the network, } \\
\text { individual organisational } \\
\text { perspective dominates } \\
\text { renewal phase as } \\
\text { assessment of strategic } \\
\text { value of re-engagement is } \\
\text { considered }\end{array}$ & $\begin{array}{l}\text { Learning occurring as a } \\
\text { consequence of knowledge } \\
\text { exchange alters relative } \\
\text { partner power and thus need } \\
\text { for synthesis of both } \\
\text { network objectives and } \\
\text { those of individual partners } \\
\text { to maintain network } \\
\text { sustainability. }\end{array}$ \\
\hline $\begin{array}{l}\text { Contraction- } \\
\text { Expansion }\end{array}$ & $\begin{array}{l}\text { Scale of partner numbers } \\
\text { remained relatively } \\
\text { constant to facilitate } \\
\text { interaction and } \\
\text { management. However, }\end{array}$ & $\begin{array}{l}\text { Scientific trajectories in } \\
\text { constant state of contraction- } \\
\text { expansion as research } \\
\text { validates or rejects } \\
\text { hypotheses and more }\end{array}$ & $\begin{array}{l}\text { Individual re-engagement is } \\
\text { strategic but individualistic } \\
\text { perspectives endeavour to } \\
\text { expand networks scientific } \\
\text { capability in trajectories }\end{array}$ & $\begin{array}{l}\text { While relational governance } \\
\text { nurtures the operational } \\
\text { success of knowledge } \\
\text { discovery, renewal } \\
\text { decisions based on }\end{array}$ \\
\hline
\end{tabular}




\begin{tabular}{|l|l|l|l|l|}
\hline & $\begin{array}{l}\text { scale of resourcing and } \\
\text { scientific trajectories } \\
\text { expands in line with } \\
\text { industry requirements. }\end{array}$ & $\begin{array}{l}\text { attractive trajectories emerge } \\
\text { to be pursued }\end{array}$ & $\begin{array}{l}\text { beneficial to their } \\
\text { organization. This impacts } \\
\text { other tensions such as } \\
\text { conflict-compromise and } \\
\text { individual-collectivism. }\end{array}$ & $\begin{array}{l}\text { alignment with individual } \\
\text { organisational goals and } \\
\text { success at value } \\
\text { appropriation. }\end{array}$ \\
\hline $\begin{array}{l}\text { Replication- } \\
\text { Innovation }\end{array}$ & $\begin{array}{l}\text { The network knowledge } \\
\text { vision driving knowledge } \\
\text { co-creation ensures all } \\
\text { partners focused on } \\
\text { innovation rather than } \\
\text { replication. }\end{array}$ & $\begin{array}{l}\text { Network focused on } \\
\text { knowledge discovery for } \\
\text { innovation. However, the } \\
\text { tension between competing } \\
\text { research increases } \\
\text { competition within network } \\
\text { teams and can ripple across } \\
\text { other dialectic dimensions. } \\
\text { Academic PI role is central to } \\
\text { synthesising tension and } \\
\text { optimising knowledge co- } \\
\text { creation capability. }\end{array}$ & $\begin{array}{l}\text { Strategic innovative } \\
\text { potential of the knowledge } \\
\text { generated by the network } \\
\text { drives engagement. To } \\
\text { prevent network } \\
\text { contraction, the network } \\
\text { must nurtures novel } \\
\text { scientific trajectories to fill } \\
\text { partner structural holes and } \\
\text { add value. }\end{array}$ & $\begin{array}{l}\text { To ensure ongoing } \\
\text { discovery, relational } \\
\text { governance is highly } \\
\text { evident and dependent on } \\
\text { partner representatives } \\
\text { championing of the } \\
\text { network. Any trend } \\
\text { towards replication rather } \\
\text { than innovation would } \\
\text { jeopardise this 'sweet-spot' } \\
\text { that fulfils both university } \\
\text { and industry objectives. }\end{array}$ \\
\hline
\end{tabular}

Table 2: Network development stage tensions and governance considerations

It is the network's management team (and primarily that of the lead academic given their centrality) that assess the disruptive potential of these tensions and determine if intervention is required. The case highlights the need to for governance at each of these three levels to achieve the required knowledge exchange and synthesis. The case also highlights the presence of certain tensions can have a positive impact on the collective knowledge capability (e.g. competing opinions of researchers regarding scientific trajectory). Often tensions stimulate individual debate and experimentation, resulting in new research trajectories and learning for those involved.

"It all comes down to the science it the end... getting the right people in the right environment moves things in unexpected ways. Decisions to allow industry secondments into the university labs were initially viewed as an inconvenience but have proved invaluable... creating multiple channels of knowledge flow between organisational partners and scaling knowledge transfer" [AC3-D].

The analysis highlights that the dialectic pairs identified by de Rond Bouchikhi (2004) are in a constant state of flux against one another and that effective governance often endeavours to stimulate them rather than to dampen them. Thus, the experience acquired by the management team from its past interventions (both planned and serendipitous) underpins ability to make more enlightened interventions of the network's knowledge management process and develop a deeper appreciation of when tensions require intervention and when they should be left alone to nurture the process in their own right. Thus, it is the outcome of these interventions (both positive and negative) that have provided the network with its knowledge management capability. In this particular network, the academic PI has taken on the role of network architect, monitoring emerging tensions and guiding governance mechanisms to ensure alignment with partner objectives to maintain synergies.

"X has visibility of the project results from all teams and also the compounds being submitted by the industrial partners for testing. This gives him insight into the partners research directions and he can ensure the projects being undertaken within the university labs align with partner's development pipline” [AC3-B]. 
Examining the network governance currently evident to support knowledge management highlights a mixture of contractual agreed, structural routines and organic relational practices that have evolved to support operations. Examples of advantageous structural routines steering knowledge exchange include defined inputs and duration of collaboration, network management team structure and membership rights, scheduled of minimal number of meetings for knowledge disseminate and partner rights to curtail access to the network. Examples of relational practices include secondment of staff into partner labs, extending the length of quarterly gatherings to incorporate social events for partner networking, addition funding for one-to one research projects, parallel to core network activity and development of a rich tapestry of communication channels for knowledge exchange across the network nodes. The governance mechanisms introduced for knowledge management are often speculative interventions in response to emerging network tensions and their introduction can have unforeseen consequences on knowledge capability (both positive and negative) and create new tensions within the system. In adopting a dialectical perspective of the inter-organisational relationship, there is an implicit rejection of the positive perspective of homogeneity and best practice for such knowledge alliances (de Rond and Bouchikhi, 2004). Instead, these knowledge governance mechanisms that exist within the network are just one manifestation of tensions synthesis and emerging governance mechanisms will create a circular condition that then impacts on emerging tensions and the knowledge creation capability realised. The ability of management to navigate these competing tensions and deliver value to multiple independent organisations is achieved through a dialectic tension of the structural and relational dimensions of governance. Relational governance helps absorb shocks in times of uncertainty and encourages individuals to exceed their contractual agreements in pursuit of opportunity. However, such practice is always in tension with the contractual agreements of the structural agreements and the required due diligence required by partner organisations.

\section{Discussion and Conclusions}

Given the longevity of the case and the significant resource commitment of industrial partners over its lifetime, then it is not unreasonable to label it an example of successful triple helix engagement of university, industry and societal stakeholders. The case is evidence that the triple helix model is achievable, especially when the focus is on exploratory research engagement where more natural synergies exist with university's traditional academic missions. From an academic perspective, the engagement with industry has furthered research though the availability of additional supports such as scientific compounds, equipment and finance, enhancing reputation of the research centre and its PI's. This case also provides evidence of the academic 'Matthew effect' (Merton, 1968) where individual success/reputation of the lead academic PI and his research centre, has attracted further research funding and generated a virtuous circle of achievement and returns on those achievements. The importance of the human element in university-industry engagement also comes to the fore, with the case highlighting the core role of the entrepreneurial academic, not only in creating the original network opportunity but also in behaving as network architect and boundary spanner, synthesising competing 
tensions and ensuring continued alignment of partner and network objectives. This finding aligns with the research of Perkmann et al., (2013) who found that key individuals' characteristics such as seniority within their organisation, established reputation for high research quality and success and experience of working with industry, were antecedents of academic external engagement with industry. The case also highlights the need for governance mechanisms to allow for the network to gel and develop the necessary appreciation of partner perspectives and routines of practice to achieve the desired knowledge exchange and synthesis. This resonates with findings of Philpott et al., (2011) who argue that transition towards the entrepreneurial university ideal and associated triple helix model is a journey towards harder entrepreneurial channels of interaction and that external engagement as opposed to those of commercialisation fit better with the attitudes of academics (Perkmann et al., 2013). Thus, the experience that partner representatives have gained through collaborating within the network reduces cognitive distance between partners and enhances their ability to effectively govern the collective knowledge management process.

Adopting a dialectical thinking perspective of the case provides a deeper understanding of the structural and relational governance mechanisms guiding knowledge exchange and discovery. The case exemplifies the complexity and uniqueness of inter-organisational relations supporting the knowledge process and resonates with the knowledge capability categorisation of vision, place, creative routines, incentives and distributed leadership identified by Nonaka and Toyama (2002). In contributing to the understudied dialectic perspective of dynamic processes within organisations, the research highlights the presence of the dialectic tensions identified by de Rond and Bouchikhi (2004) within the case and also the interrelationship across these tension pairs. The case highlights the complexity of networks since management intervention to address one tension pair at one level of the network can inadvertently stimulate tension (in a positive or negative manner) in an alternative tension pair at the same level of the entity or at a different level, altering the reality of the network and capability of its knowledge process. Governance interventions by management must be cognisant of this complexity when intervening to nurture the knowledge process and alert to unforeseen consequences of such interventions. Analysis of the case's knowledge process highlights presence of dialectic tensions can be advantageous for knowledge exchange, creativity and innovation and on occasion, may need to be stimulated within the network by management rather than dampened, in order to stimulate learning. Rather than something to be avoided within inter-organisation relations, the analysis finds these dialectic tensions are natural part of human interaction and that it is management's response to these tensions that will determine efficacy of the knowledge process. This aligns with de Rond and Bouchikhi's (2004) viewpoint that dialectic tensions are a natural occurrence in inter-organisational relationships and not an indicator of instability or network demise as suggested by Das and Teng's (2000a; 2000b).

Reflecting on the nature of governance leveraged from network formation to current state, the case study analysis highlights that although there was an initial reliance on structural governance mechanisms, as social relationships developed, then the prevalence of relational governance mechanisms increased. However, this 
development did not reduce the need for structural governance mechanisms and instead both structural and relational governance mechanisms co-exist within the network to guide the knowledge process. In terms of the structural and relational dimensions of the network's knowledge governance, the findings highlight the importance of structural governance (e.g. contractual terms) when tensions are extreme and relational governance is unable to synthesis a feasible resolution. Structural governance provides the assurance of a minimum threshold of engagement between the parties and a 'window of interaction opportunity' to resolve disruptive tensions. While the structural governance mechanisms nurtures network stability, it is the relational dimension of governance that underpinned stakeholder adaptability in synthesis resolutions to emerging tensions (although always in the shadow of the contractual terms). Relational ties at higher levels of the network, together with a degree of line-control of partner representatives within their organisations, often creates the 'space and time' for individuals at lower levels of the network to achieve cognitive proximity with peers and develop their own network of relational ties and channels of communication. This enriches the tapestry of social connections within the network, further stimulating its knowledge exchange, creativity and innovation capability. While relational governance facilitates partners exceeding structural commitments for the collective benefit, such decisions are taken cognisant of their stewardship role to their parent organisation. Thus relational governance while important in supporting inter-organisational collaboration, should not be overstated since it exists in constant tension with the structural need to deliver value to the partner organisation. Thus, within mature network, rather than relational governance superseding structural governance mechanisms, both are required for effective governance. Inter-organisational knowledge exchange is itself a dialectic tension between these structural and relational dimensions to governance.

The case highlights that although governance mechanisms influence the tensions within the knowledge process, there is also evidence that tensions (constraining or stimulating) arising from the knowledge process influence the evolution of the network's governance mechanisms. This interrelationship between the knowledge process and governance mechanisms supports Foss's (2013) perspective that knowledge can be viewed as a dependent variable where the governance mechanisms influence the exchange, absorption and synthesis occurring within the knowledge process but also viewed as an independent variable, capable of influencing the governance mechanisms within the network. Management must be conscious of this interrelationship in their efforts to steer developments within the network's knowledge process for synthesis and mutual benefit. The case highlights that the governance response to emerging tensions within interorganisational relations is very much trial and error since network complexity makes it difficult to appreciate fully appreciate the implications of any intervention. Thus experience of the management team is core to identify if and what interventions may be required in response to emerging dialectic tensions.

The implications of the case analysis from a practice perspective are four fold. Firstly, it offers national policy makers insights into dialectical management tensions of university-industry collaboration and the contextual heterogeneity that impacts the dynamic development of such entities. Second, it provides insights for managers 
of knowledge networks about the interplay between structural and relational dimensions of network governance and emphasises that both must be leveraged. It also highlights that management should not strive to eradicate the presence of tensions within dialectic pairs given they can have positive impact on creativity and instead should seek to synthesis solutions that enhance knowledge creation capability. Third, the research provides insights into the importance of management to develop appropriate governance mechanisms at the micro, meso and macro level of the network to nurture the knowledge process for discovery and mutual benefit. Lastly, the case analysis highlights the centrality of the entrepreneurial academic in governance of the university-industry network and the required long-term partner representative commitment to achieve the desired knowledge co-creation.

\section{Limitations of the research}

Whilst this research has provided a fine-grained exploration into developing governance within an interorganisational knowledge process, the findings are limited to a single case of university-industry knowledge exchange network, within the context of a life-sciences research centre. The single case research approach aligns with the dialectical epistemology, which dismisses the expectation of homogeny or constancy across network cases but consequently, the external validity remains limited. The tensions encountered and the governance mechanisms adopted to nurture the network's knowledge process are influenced by the nature of the exploratory research being undertaken, the scale of the organisations involved, the characteristics, actions and experiences of the organisational representatives on the network's management team and developments occurring at the partner organisational level and the macro environmental level during the networks existence. This is in keeping with the complexity of the network environment that management must consider when selecting interventions to enhance the inter-organisational knowledge process. However, it does not suggest best practice with respect to governance of inter-organisational knowledge networks. 


\section{References}

Barringer, B.R. and Harrison, J.S. (2000) Walking a Tightrope: Creating value through inter-organisational relationships, Journal of Management, Vol. 26, No. 3, 367-403.

Beamish, P. W. (1988). Multinational joint ventures in developing countries. London: Routledge.

Becheikh, N., Landry, R., Amara, N., (2006). Lessons from innovation empirical studies in the manufacturing sector: a systematic review of the literature from 1993-2003. Technovation 26, 644-664.

Beeby, M. and Booth, C., 2000. Networks and inter-organizational learning: a critical review. The learning organization, 7(2), pp.75-88.

Blackler, F. (1995). Knowledge, Knowledge Work and Organisations: An Overview and Interpretation, Organisation Studies, 16 (6), pp. 1021-1046.

Blau, P., 1964. Power and exchange in social life. New York: $J$ Wiley \& Sons.

Bojica, A.M., Estrada, I. and del Mar Fuentes-Fuentes, M., 2018. In Good Company: When Small and Medium-Sized Enterprises Acquire Multiplex Knowledge from Key Commercial Partners. Journal of Small Business Management, 56(2), pp.294-311.

Brown, J.S. and Duguid, P. (1991). Organisational learning and communities-of-practice: toward a unified view of working, learning, and innovating: Organisation Science; Feb, Vol. 2 Issue 1, p40-57.

Burt, R. S. (1992). Structural Holes: The social structure of competition (1st ed.). Cambridge, MA: Harvard University Press.

Cerchione, R., Esposito, E. 2016. A systematic review of supply chain knowledge management research: State of the art and research opportunities. International Journal of Production Economics, 182, pp. 276-292)

Chesbrough, H.W. (2003). Open Innovation: The new imperative for creating and profiting from technology. Boston; Harvard Business School Press.

Chiesa, V. and Piccaluga, A. (2000), "Exploitation and diffusion of public research: the case of academic spinoff companies in Italy", R\&D Management, Vol. 30 No. 4, pp. 329-39.

Child, J., Faulkner, D., Tallman, S. and Tallman, S.B., 2005. Cooperative strategy. Oxford University Press, USA.

Cohen, W.M. and Levinthal, D.A. (1990). Absorptive Capacity: A New Perspective on Learning and Innovation: Administrative Science Quarterly, Mar., Vol. 35 (1), pp. 128-152

Contractor, F.J., (2005). Alliance structure and process: will the two research streams ever meet in alliance research?. European Management Review,2(2), pp.123-129.

Das, T., Teng, B., (2000a). A resource-based theory of strategic alliances. Journal of Management 26 (1), $31-61$. 
Das, T.K. and Teng, B.S., (2000b). Instabilities of strategic alliances: An internal tensions perspective. Organisation science, 11(1), pp.77-101.

de Faria, P., Lima, F. and Santos, R. (2010). Cooperation in innovation activities: The importance of partners. Research Policy, 19, 1082-1092.

De Rond, M. (2003) Strategic Alliances as Social Facts: Business, biotechnology and Intellectual history. UK: Cambridge University Press

De Rond, M. and Bouchikhi, H., (2004). On the dialectics of strategic alliances. Organisation Science, 15(1), pp.56-69.

Debackere, K. (2000), "Managing academic $R \& D$ as a business at KU Leuven: context, structure and process", R\&D Management, Vol. 30 No. 4, pp. 323-8.

Dooley L., Kirk R.D. and Philpott K. (2013). Managing collaboration in knowledge discovery networks. Journal of Production, Planning and Control, Vol. 24, (2-3), 195-207.

Doso, G and Marengo, L. (1994). Some elements of an evolutionary theory of organisational competences. The theory of the firm : Critical perspectives on business and management, ed. N.J. Foss. Routledge Publishing : UK.

Doz, Y.L and Hamel, G. (1998). Strategic Advantage. Harvard Business School Press: Boston.

Eisenhardt K.M. and Schoonhoven, C.B. (1996). Resource-based View of Strategic Alliance Formation: Strategic and Social Effects in Entrepreneurial Firms, Organisation Science, Mar/Apr., Vol. 7 Issue 2, pp. $136-150$

Eisenhardt, K.M. (1989). Building Theories from Case Study Research. Academy of Management Review, Vol. 14, No. 4, 532-550.

Elmuti, D., Abebe, M. and Nicolosi, M. (2005). An overview of strategic alliances between universities and corporations, The Journal of Workplace Learning, Vol. 17 Nos 1/2, pp. 115-28.

Etzkowitz H., Leydesdorff, L. (2000). The Dynamics of Innovation: from National Systems and "Mode 2" to a Triple Helix of University-industry-government Relations, Research Policy, 29, 109-123

Etzkowitz, H., Webster, A., Gebhardt, C. and Terra, B.R.C., (2000). The future of the university and the university of the future: evolution of ivory tower to entrepreneurial paradigm. Research Policy, 29(2), pp.313-330.

Faems, D., Janssens, M., Madhok, A. and Van Looy, B., (2008). Toward an integrative perspective on alliance governance: Connecting contract design, trust dynamics, and contract application. Academy of management journal,51(6), pp.1053-1078.

Farrar, J., 2008. Corporate governance: theories, principles and practice. Oxford University Press. 
Foss, N.J., 2013. Knowledge governance: meaning, origins and implications. Handbook of Economic Organisation: Integrating Economic and Organisation Theory, p.62.

Fritsch, M. and Kauffeld-Monz, M., 2010. The impact of network structure on knowledge transfer: an application of social network analysis in the context of regional innovation networks. The Annals of Regional Science, 44(1), p.21.

Glaser, B.S. and Strauss, A., 1968. A. (1967). The discovery of grounded theory. Strategies for qualitative research. London: Weidenfeld and Nicolson.

Grandori, A., 2001. Neither hierarchy nor identity: knowledge-governance mechanisms and the theory of the firm. Journal of management and Governance, 5(3-4), pp.381-399.

Granovetter, M. S. (1973). 'The Strength of Weak Ties'. American Journal of Sociology, 78(6), 1360-1380.

Gredler, M.E. (1997) Learning and instruction: Theory into practice. Prentice-Hall Inc. (New Jersey).

Gubbins, C. and Dooley, L. (2013). Exploring Social Network Dynamics Driving Knowledge Management for Innovation. Journal of Management Inquiry, 23(2), 162-185.

Hagedoorn, J. (1995). A Note on International Market Leaders and Networks of Strategic Technology Partnering, Strategic Management Journal, Vol. 16 (3), 241-250

Hansen, M. T. (1999), “The Search-Transfer Problem: The Role of Weak Ties in Sharing Knowledge across Organisation Subunits”, Administrative Science Quarterly, vol. 44, (1), 82-111.

Hargadon, A.B. (2002). 'Knowledge brokering: A network perspective on learning and innovation', in Research in Organisational Behavior, Straw, B. and Kramer, R. (Eds), JAI Press, 21: pp. 41-85

Huggins, R., Johnston, A., Stride, C. (2013) Knowledge networks and universities: Locational and organisational aspects of knowledge transfer interactions. Entrepreneurship and Regional Development 24(7-8), pp. 475-502

Inkpen A.C. (1996). Creating knowledge through collaboration. California Management Review Vol. 39, No. $1,123-140$.

Ilvonen, I., Vuori, V. (2013) Risks and benefits of knowledge sharing in co-opetitive knowledge networks. International Journal of Networking and Virtual Organisations, 13(3), pp. 209-223

Kang, K.N., Lee, Y.S., (2008). What affects the innovation performance of small and medium-sized enterprises (SMEs) in the biotechnology industry? An empirical study on Korean biotech SMEs. Biotechnology Letter 30, 1699-1704.

Kleinknecht, A. and Reijnen J.O. (1992). Why do Firms Cooperate on R\&D? An Empirical Study. Research Policy, Vol. 21, Issue 4, 347-360

Kogut, B. (1989). The Stability of Joint Ventures: Reciprocity and Competitive Rivalry. The Journal of 
Industrial Economics, Vol. 38, No.2, 183-198

Madhok, A. and Tallman, S.B., (1998). Resources, transactions and rents: Managing value through interfirm collaborative relationships. Organisation science, 9(3), pp.326-339.

Merton, R.K., 1968. The Matthew effect in science: The reward and communication systems of science are considered. Science, 159(3810), pp.56-63.

Miles, M.B. and Huberman, A.M., (1994). Qualitative data analysis: An expanded sourcebook. Sage.

Nonaka, I. and Toyama, R. (2002). A firm as a dialectical being: towards a dynamic theory of a firm, Industrial and Corporate Change, Volume 11, Issue 5, 1, pp. 995-1009.

Pascale, R.T., (1990). Managing on the Edge. Simon and Schuster.

Perkmann, M., Tartari, V., McKelvey, M., Autio, E., Broström, A., D’Este, P., Fini, R., Geuna, A., Grimaldi, R., Hughes, A. and Krabel, S., 2013. Academic engagement and commercialisation: A review of the literature on university-industry relations. Research policy, 42(2), pp.423-442.

Pettigrew, A.M., (1987). Context and action in the transformation of the firm.Journal of management studies, 24(6), pp.649-670.

Philpott, K., Dooley, L., O'Reilly, C. and Lupton, G., (2011). The entrepreneurial university: Examining the underlying academic tensions. Technovation, 31(4), pp.161-170.

Powell, W. (1990). Neither market nor hierarchy: network forms of organisation, in B.M. Staw and L.L. Cummings (eds.) Research in Organisational Behavior, JAI Press, 295-336.

Powell, W., Koput, K.W. and Smith-Doerr, L. (1996). Inter-organisational collaboration and the locus of innovation: Networks of learning in biotechnology, Administrative Science Quarterly, 41, 116-145.

Powell, W.W. (1998). Learning from Collaboration: Knowledge and Networks in the Biotechnology and Pharmaceutical Industries. California Management Review, 40(3), 228-240

Provan K.G. and Kenis, P. (2008), Modes of Network Governance: Structure, Management, and Effectiveness, Journal of Public Administration Research and Theory, Vol.18 (2), 229-252

Robbins-Roth, C. (2001). From Alchemy to IPO: The business of biotechnology, Perseus Publishing: Cambridge (USA)

Romijn, H., Albaladejo, M., (2002). Determinants of innovation capability in small electronics and software firms in southeast England. Research Policy 31, 1053-1067.

Rothwell, P.A. (1992). Successful industrial innovation: critical factors for the 1990s, R\&D Management, Vol. $22(3), 221-240$.

Rothwell, P.A. (1994). Towards the Fifth-generation Innovation Process. International Marketing Review, Vol. 11 (1), 7 - 31. 
Sanchez, R. (1997) Preparing for an Uncertain Future: Managing Organisations for Strategic Flexibility. International Studies in Management and Organisation, Summer, 71-94.

Senge, P.M., (1990). The art and practice of the learning organisation (pp. 3-11). New York: Doubleday.

Spekman, R.E., Isabella, L.A., MacAvoy, T.C., Forbes, T. (1996). Creating Strategic Alliances which Endure. Long Range Planning. Vol. 29, No. 3, 346-357.

Strauss, A. L. and Corbin, J. (1990). Basics of Qualitative Research. Newbury Park, CA: Sage.

Swan, J. and Newell, S., (1999). Central Agencies in the Diffusion and Design of Technology: A Comparison of the UK and Sweden. Organisation Studies, Vol. 20 Issue 6, 905-931

Swan, J. and Scarbrough, H. (2001). Knowledge Management: Concepts and controversies. Journal of Management Studies, Nov., Vol. 38 (7), 913-921

Sydow, J., Schubler, E. and Muller-Seitz, G. (2016). Managing Inter-Organisational Relations. Palgrave Publishing: London.

Teece, D.J., Pisano, G. and Shuen, A., (1997). Dynamic capabilities and strategic management. Strategic management journal, 18(7), pp.509-533.

Tepic, M., Omta, O., Trienekens, J. and Fortuin, F., 2011. The role of structural and relational governance in creating stable innovation networks: Insights from sustainability-oriented Dutch innovation networks. Journal on Chain and Network Science, 11(3), pp.197-211.

Tidd, J., Bessant, J. and Pavitt, K. (2005). Managing Innovation - Integrating Technological, Market and Organisational Change, Chichester: John Wiley \& Sons (3rd Edition).

Tranfield, D., Young, M., Partington, D., Bessant, J., \& Sapsed, J. (2006). Knowledge management routines for innovation projects: Developing a hierarchical process model. In J. Tidd (Ed.), Knowledge management to strategic competence (2nd ed., pp. 126-149). London, England: Imperial College Press.

Van de Ven, A.H. and Poole, M.S., (1995). Explaining development and change in organisations. Academy of management review, 20(3), pp.510-540.

Williamson, O.E., (1985). The economic intstitutions of capitalism. Simon and Schuster.

Yin, R.K. (2002) Case Study Research: Design and Methods, Sage Publications, London. 